\title{
Erythema nodosum-like lesion on heel in a patient assumed Behçet's disease
}

\author{
Hiroshi Takase [1] , Taro Shimizu
}

Department of Diagnostic and Generalist Medicine, Dokkyo Medical University Hospital, Shimotsuga-gun, Tochigi, Japan

\section{Correspondence to Dr Hiroshi Takase; dzand@hotmail.co.jp}

Accepted 31 October 2019

\section{DESCRIPTION}

A 35-years-old Japanese man was evaluated for fever and right heel pain. One year prior, he had an episode of fever, stomatitis, oligoarthralgia, lumbago and blurred vision. Despite the extensive investigations, he only had a diagnosis of uveitis with unknown aetiology and all the symptoms remitted without specific treatments during a month. One month prior, his fever and the symptoms recurred and right heel pain was gradually emerged. Local physicians gave him oral antibiotics and nonsteroidal anti-inflammatory drugs (NSAIDs) under the working diagnosis of heel cellulitis, but the lesion was persisted. He denied dyspnoea, cough, chest pain, abdominal pain, diarrhoea, heel injury, genital ulcers and the other skin lesions.

At the time of presentation, he was afebrile with oral diclofenac. Eyes were slightly congested. On examination of right heel, there was a $5-\mathrm{cm}$ circular, poorly demarcated and erythematous lump (figure 1). MRI without contrast revealed heel panniculitis without osteomyelitis nor thrombophlebitis (figure 2). Ophthalmologist diagnosed bilateral panuveitis, and blood test showed the positivity of HLA-A*26 and B*51. His all episodes were explained by Behçet's disease (BD) depending on the panuveitis, aphthous stomatitis, arthritis and HLA typing. The heel lesion was assumed to be an atypical erythema nodosum (EN) or an EN-like lesion as a result of vasculitis, for example, phlebitis. Diclofenac was switched to colchicine. Fever and the heel pain were remitted but adalimumab was added to control panuveitis. After 2 months, he

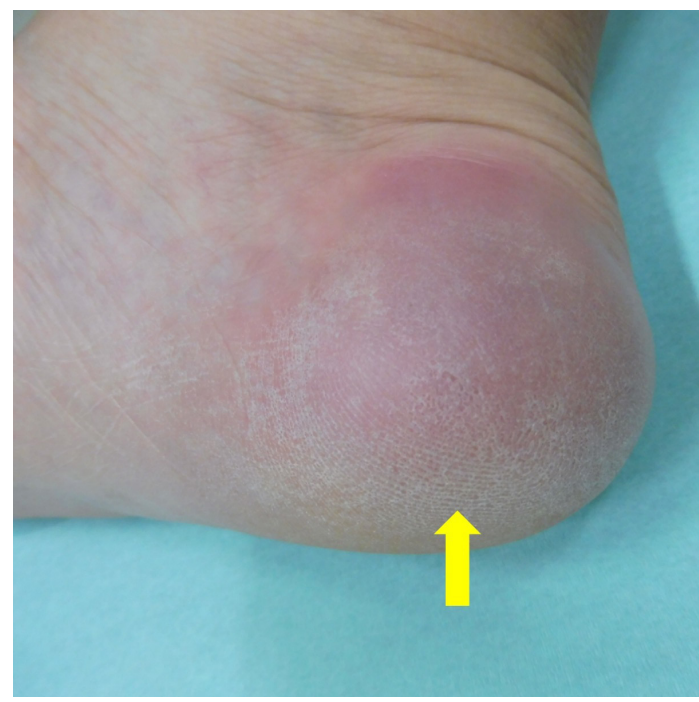

Figure 1 The erythematous lesion on right heel (arrow).

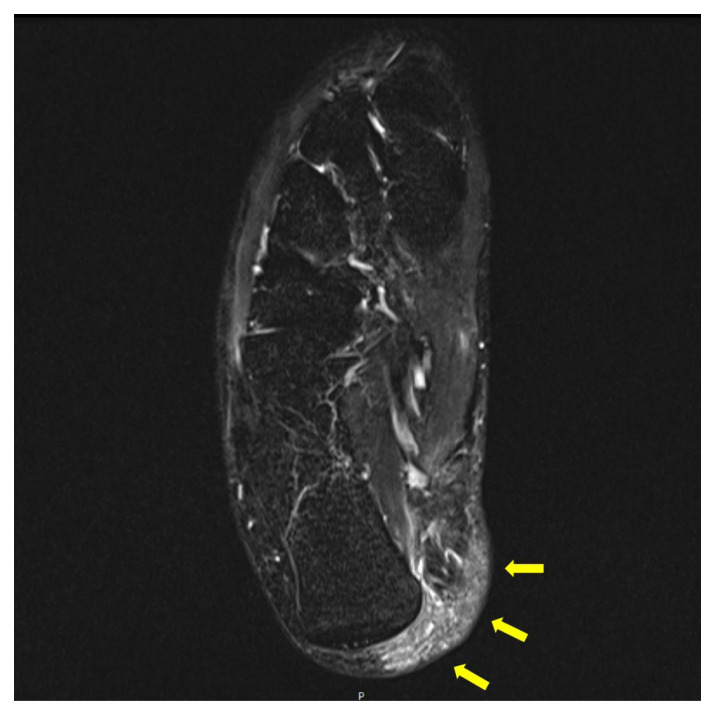

Figure 2 T2-weighted short-tau inversion recovery image of the heel. Subcutaneous fat tissue on medial side of right heel shows high signal intensity (arrows), which is consistent with panniculitis. Surrounding fascia also shows high intensity but no signal changes in bones or vessels.

had no symptoms and the heel lesion diminished completely.

$\mathrm{BD}$ is a systemic inflammatory condition triggered by undetermined complex aetiology in genetically predisposed individuals. ${ }^{1}$ The concept of disease was established in 1937 by a dermatologist, Hulusi Behçet. ${ }^{2}$ In spite of the history, skin lesions of $\mathrm{BD}$ are often not easy to distinguish from the lesions caused by other aetiologies. This is because large variety of skin manifestations can occur in $\mathrm{BD}$, including pseudofolliculitis, pyoderma gangrenosum and EN-like lesions caused by vascular involvement. ${ }^{3}$ We could not easily accept his lesion as 'single EN on heel', as it is scarcely reported in literatures. ${ }^{3-5}$ MRI sometimes help to reveal the presence of vasculitis on foot, ${ }^{6}$ but did not in this case. Biopsy was considered but not performed because it is invasive and we thought other clues including panuveitis are enough to classify him as BD.

There are at least 17 diagnostic/classification criteria for BD which have various diagnostic sensitivities and specificities. ${ }^{7}$ His presentations met some of these criteria including Japanese one, and not others including International Study Group diagnostic criteria unless we regard the heel lesion as consistent with $\mathrm{BD} .{ }^{8}$ It is still important to accumulate atypical dermatological findings of $\mathrm{BD}$ for 
further better diagnostic procedure, even though many decades have passed since the name was established.

\section{Patient's perspective}

All doctors I met before called the heel 'cellulitis', but antibiotics were not effective. So, I was relieved to be diagnosed.

\section{Learning points}

- A patient who has an unusual painful erythematous lesion with panuveitis may be Behçet's disease (BD).

- Skin findings are keys to diagnose $\mathrm{BD}$, although it is often difficult to distinguish typical ones from others caused by different aetiologies.

- For an atypical erythema nodosum-like lesion, skin biopsy is the gold standard to investigate underlying causes, but MRI may be a non-invasive alternative to add a diagnostic information.

Contributors HT was in charge of patient care, took pictures of the lesion, obtained consent from him and wrote all the main manuscript first. TS was revised the manuscript.
Funding The authors have not declared a specific grant for this research from any funding agency in the public, commercial or not-for-profit sectors.

Competing interests None declared.

Patient consent for publication Obtained.

Provenance and peer review Not commissioned; externally peer reviewed.

\section{ORCID iD}

Hiroshi Takase http://orcid.org/0000-0001-7339-4109

\section{REFERENCES}

1 Leccese P, Alpsoy E. Behçet's disease: an overview of etiopathogenesis. Front Immunol 2019:10:1067.

2 Behçet H, Matteson EL. On relapsing, aphthous ulcers of the mouth, eye and genitalia caused by a virus. 1937. Clin Exp Rheumatol 2010;28:S2-5.

3 Scherrer MAR, Rocha VB, Garcia LC, et al. Behçet's disease: review with emphasis on dermatological aspects. An Bras Dermatol 2017;92:452-64.

4 Schwartz RA, Nervi SJ. Erythema nodosum: a sign of systemic disease. Am Fam Physician 2007;75:695-700.

5 Misago N, Tada Y, Koarada S, et al. Erythema nodosum-like lesions in Behçet's disease: a clinicopathological study of 26 cases. Acta Derm Venereol 2012;92:681-6.

6 Miranda FC, Carneiro RD, Longo CH, et al. Plantar thrombophlebitis: magnetic resonance imaging findings. Rev Bras Ortop 2012;47:765-9.

7 Davatchi F, Sadeghi Abdollahi B, Chams-Davatchi C, et al. The SAGA of diagnosticl classification criteria in Behcet's disease. Int J Rheum Dis 2015;18:594-605.

8 Kirino Y, Nakajima H. Clinical and genetic aspects of Behçet's disease in Japan. Intern Med 2019;58:1199-207.

Copyright 2019 BMJ Publishing Group. All rights reserved. For permission to reuse any of this content visit

https://www.bmj.com/company/products-services/rights-and-licensing/permissions/

BMJ Case Report Fellows may re-use this article for personal use and teaching without any further permission.

Become a Fellow of BMJ Case Reports today and you can:

- Submit as many cases as you like

- Enjoy fast sympathetic peer review and rapid publication of accepted articles

- Access all the published articles

Re-use any of the published material for personal use and teaching without further permission

Customer Service

If you have any further queries about your subscription, please contact our customer services team on +44 (0) 2071111105 or via email at support@bmj.com.

Visit casereports.bmj.com for more articles like this and to become a Fellow 